\title{
THE TWO PARTS OF THE "MITHRAIC UNIVERSE" BY RIGHT OF THE EXTERNAL AND INTERNAL ORIENTATION OF THE CULT IMAGE
}

\author{
ESSAY
}

In memoriam Zeke Mazur

Summary: The external orientation of the Mithraic sanctuaries shows a great variety and heterogeneity. The internal orientation of the sanctuaries suggested by the cult image, however, shows a great homogenity and uniformity. The internal structure is organised on the possible axial line drawn from the entrance to the cult image, and continues beyond that. We can establish that the interior of a mithraeum is oriented along the 'North-South - East-West' frame of reference by the cult image.

The representation of the "Cosmos" in the sanctuary portrays only the visible, sensorial world. The known and organised "Cosmos" is the sanctuary itself, the 'northern part' of the Mithraic 'Universe' with its own inner coordinates.

The 'Anti-Cosmos', the Underworld, had been abolished from the 'Mithraic Universe', completely unmentioned by literary sources. After the vertical North-South and horizontal East-West orientation we can consider, that the cult image also as a partition, divides the 'Mithraic Universe' up into 'northern' and 'southern' parts. The 'northern part', as it is displayed, the ordered part of the 'Universe', or the "Cosmos" itself is represented by the shrine. Its opposite, the 'southern part', the disordered part of the 'Universe', or 'Anti-Cosmos' is absent on the cult image.

The Tauroctony prevents the specifically represented Underworld and its principles to manifest, creating the opportunity for the initiates to continue their eternal life in the living and organized part of the 'Universe', in the "Cosmos".

Key words: Mithras, mithraeum, sacred topography, Mithraic Universe, Cosmos, Anti-Cosmos, Tauroctony

Studying the problems of the mysteries of Mithras produced a significant bibliography in the last two centuries. Some of the major issues were reanalysed based on the literary, epigraphic, papyriological, archaeological and iconographic sources. The number of the literary sources did not increase significantly since the last major corpora were published. The sanctuaries and their epigraphic material give a glimpse into the daily religious practices, but cannot reveal details on the religious system and thought of the cult. ${ }^{1}$

${ }^{1}$ Summarizing the sources, see CUMONT, F.: Textes et monuments figurés relatifs aux Mystères de Mithra. Vol. I: Introduction. Bruxelles 1896; Vol II: Textes et monuments. Bruxelles 1899; VERMASEREN, 
In the last period, the systematic analysis of the sources and the comparative study of the iconographic and literary sources led to new results. Due to this, today we know the temporal and spatial distribution of the cult, its formation and disappearance, its main symbols and their meaning, its social aspects and some of the religious thoughts of it. Beside the literary sources, the synthetic analysis of the plans of the mithraea with the internal inventories of the sanctuaries and the cult relief itself gives an holistic view of the cult. ${ }^{2}$

In the following, the paper analyses the complex structure of the mithraea and new aspects and significance of their space-dimensional structuring principal. ${ }^{3}$ For such an approach one can rely only on the best preserved and complex panelled frescoes and reliefs, for example Santa Maria Capua Vetere (fig. 2), Marino (see fig. 5) in Italy, Nida-Heddernheim, Osterburken in Germany, etc. ${ }^{4}$ The individual iconographic differences and local varieties of some of the provincial reliefs, such as the well understandable and explicable mixed representations of the torchbearers ${ }^{5}$ (for ex. Dunaújváros, ${ }^{6}$ see fig. 1 vs. Marino, see fig. 5), the missing of some of the secondary figures, $^{7}$ as well as the local varieties of the inventory, have not been considered for this general interpretation.

\section{THE MITHRAEUM}

The structural and ornamentical world of a mithraeum is unique in the sacred architecture of the Roman Empire (cf. fig. 2). Each built, carved or painted item can be identified within the sanctuary. Their uniqueness is given by their holistic structure and

M. J.: Corpus Inscriptionum et Monumentorum Religionis Mithriacae [CIMRM]. Vol. I-II. Den Haag 1956-1960; VOLKOMMER, R.: Mithras. In Lexicon Iconographicum Mythologiae Classicae VI (1992) 583-626; LÁsZló, L. - NAGY, L. - SzABÓ, Á.: Mithras és misztériumai [Mithras and His Mysteries]. Vol. I-II. Budapest 2005, II 191-243, 245-298, 299-315.

${ }^{2}$ Cf. Cumont, F.: Les mystères de Mithra. Bruxelles 1913; Vermaseren, M. J.: Mithras: Geschichte eines Kultes. Stuttgart 1965; MERKELBACH, R.: Mithras. Hain 1984; LÁSZlÓ-NAGY-SZABÓ (n. 1); BECK, R.: The Religion of the Mithras Cult in the Roman Empire. Mysteries of the Unconquered Sun. Oxford 2006; Clauss, M.: Mithras: Kult und Mysterium. Darmstadt-Mainz 2012; CHALUPA, A.: The Origins of the Roman Cult of Mithras in the Light of New Evidence and Interpretations: The Current State of Affairs. Religio 24.1 Rozhledy (2016) 65-96, with former literature.

${ }^{3}$ Some details of the topik, former, outlined, cf. SZABÓ, Á.: A mithraeumok tájolásának kérdéséhez [Notes to the Question about the Orientation of the Mithraea]. Antik Tanulmányok 56.1 (2012) 125-134.

${ }^{4}$ CIMRM 181; VOLKOMMER (n. 1) no. 145; CIMRM 1083, 1292-1293.

${ }^{5}$ Cf. BECK, R.: The Mithraic Torchbearers and 'Absence of Opposition'. Classical Views 26 (n.s. 1) (1982) 126-140. Cf. more infra.

${ }^{6}$ Intercisa, Pannonia Inferior: cf. TóTH, I. - VISY, ZS.: Das große Kultbild des Mithräums und die Probleme des Mithras-Kultes in Intercisa. Specimina Nova Dissertationum Universitatis Quinqueecclesiensis 1 (1985) 37-56 and TóTH, I.: Mithras Pannonicus. Essays. [Specimina Nova Dissertationum Universitatis Quinqueecclesiensis 17]. Budapest-Pécs 2003, 37-68.

${ }^{7}$ Cf. generally WILL, E.: Le relief cultuel gréco-romain: contribution á l'histoire de l'art de l'Empire romain [BÉFAR 183]. Paris 1955; detailed CAMPBELL, L.: Typologie of Mithraic Tauroctonies. Berytus 11 (1954-1955) 1-60, and CAMPBELL, L.: Mithraic Iconography and Ideology [EPRO 11]. Leiden 1968. 


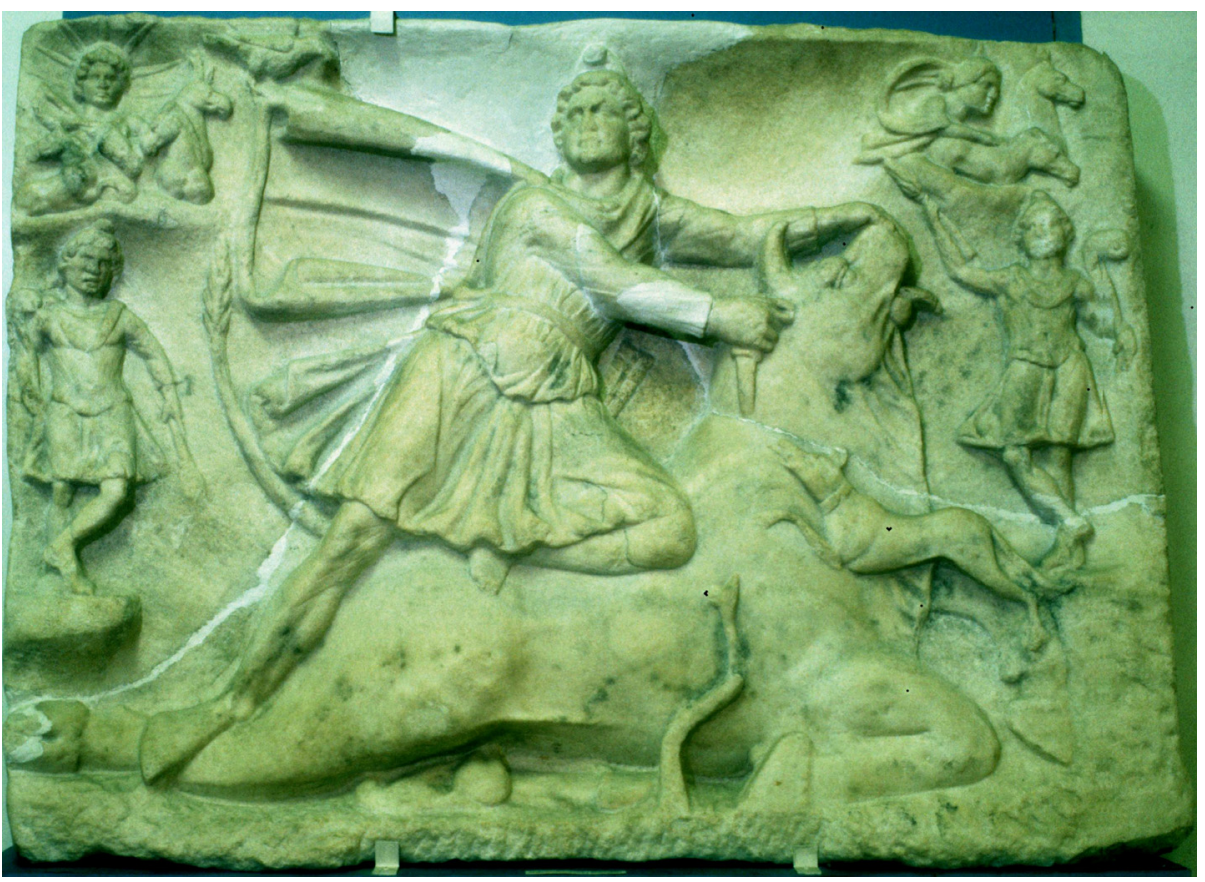

Fig. 1. The great cult relief from Intercisa (Intercisa Múzeum, Dunaújváros). Photo by Z. Mazur (Nr. 111/1999)

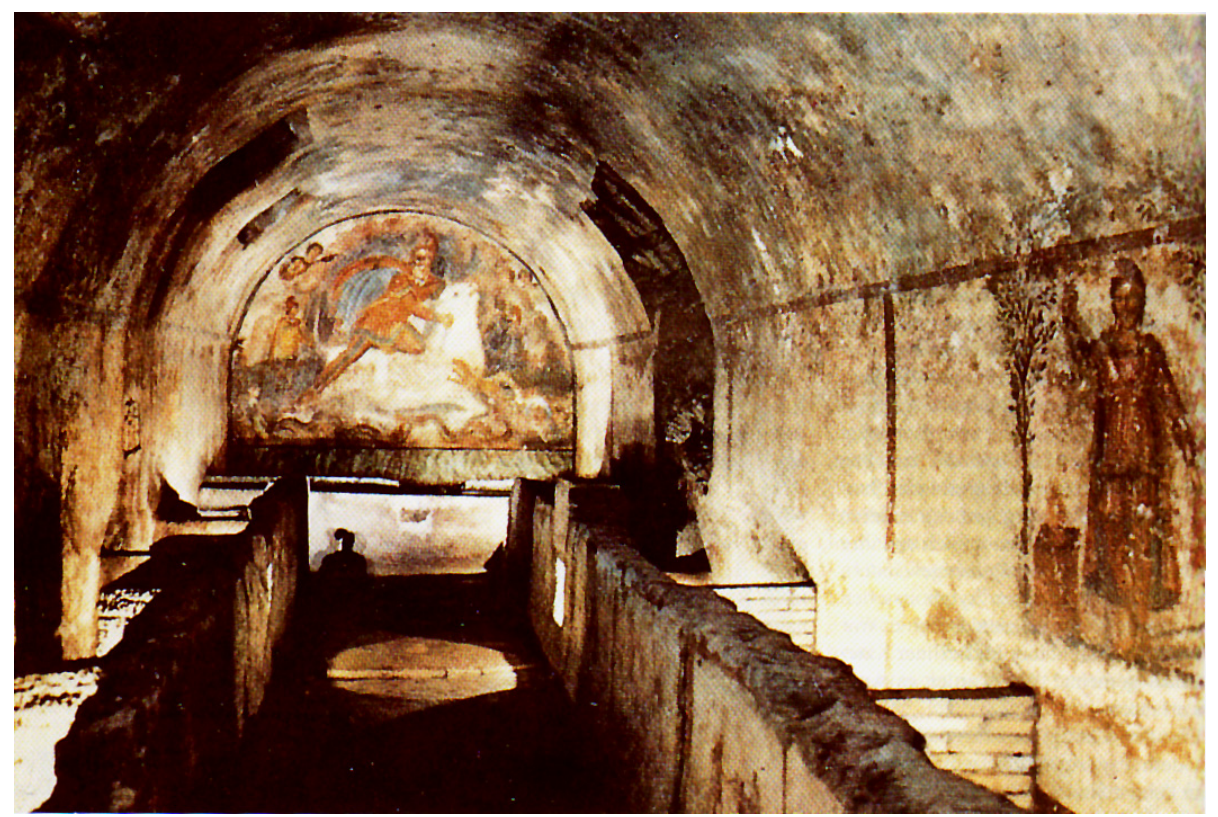

Fig. 2. St. Maria Capua Vetere Mithraeum (Italy) Photo by Z. Mazur (Nr. 77/1999) 
and system. During the existence of the mystery religion, the building itself was named by various technical, administrative, religious and legal terms. Sanctuaries with identical function in the Roman Empire known from the 1st-4th centuries AD were named by literary and epigraphic sources as templum, crypta, anthrum, spaeleum, sacellum, sacratorium, leonteum, mithraeum. Despite the terminological variations, all the buildings are following the same architectural structure and internal organisation with minor temporal or regional changes, which do not affect the essence of the mysteries and the religious practice.

The sanctuaries are imitations of a natural mythical cave and were established in a natural cavity or built underground or on the surface. The original, mythical cave is mirroring the "Cosmos", the organized universe, that was created by Mithras. Within the cave, the objects and the distances between them represent the various elements and spheres. ${ }^{8}$

From the territory of the Roman Empire, a large number of mithraea are known with identical structure. In front of the entrance stood the cult relief, on the two lateral sides the podia, while the ceiling represented the sky. Differences between the sanctuaries occured only in their external position, that adapted to the natural or artificial environment. Beside this, there could be minor distinctions in extent of their decoration and inventory. Their topographic orientation in relation to their entrance does not show any rule or system. Based on this, it seems that the religious regulations did not affect the external circumstances of the buildings. However, the organized system of their internal structure, imitating the mythical "Cosmos", influenced and defined the inner structure of the sanctuary. From this perspective in the sanctuary the celestial spheres, planets and constellations gained an important role. In relation with the "Cosmos" itself, the starting point of the sanctuary is the Earth. The depiction of the "Cosmos" as a whole, and the strict inner orientation system explain why the religious regulations did not care about the external part of the sanctuaries, either their form or their location. The worshippers who entered the sanctuary, became part of an inner system with its own principles, which differed from the outside world and its rules.

The interior of the sanctuary, the "Cosmos", its structure and orientation according to different quarters and principles were analysed in details, and the sacred topography was reconstructed by R. Gordon and supported by R. Beck (cf. figs 3-4). I. Tóth demonstrated that the sacred topography of the sanctuary also consists of a special system in the Danubian provinces. ${ }^{10}$ The starting point of their analysis was always the inner structure of the sanctuary representing a closed system.

${ }^{8}$ Cf. Porphyrios, De antro nympharum 6. Cf. more LÁszLó-NAGY-SZABÓ (n. 1) 246-247.

${ }^{9}$ See GoRDON, R. L.: The Sacred Geography of a Mithraeum: The Example of Sette Sfere. Journal of Mithraic Studies 1 (1976) 119-165; BECK (n. 2) 102-120. Cf. LÁSZLÓ-NAGY-SZABÓ (n. 1) $238-252$.

${ }^{10}$ Cf. Tóth, I.: Das lokale System der mithraischen Personifikationen im Gebiet von Poetovio. Arheoloski Vestnik 28 (1977) 385-392 = TóTH, I.: Das lokale System der mithraischen Personifikationen im Gebiet von Poetovio. In TóTH: Mithras Pannonicus (n. 6) 87-96. 


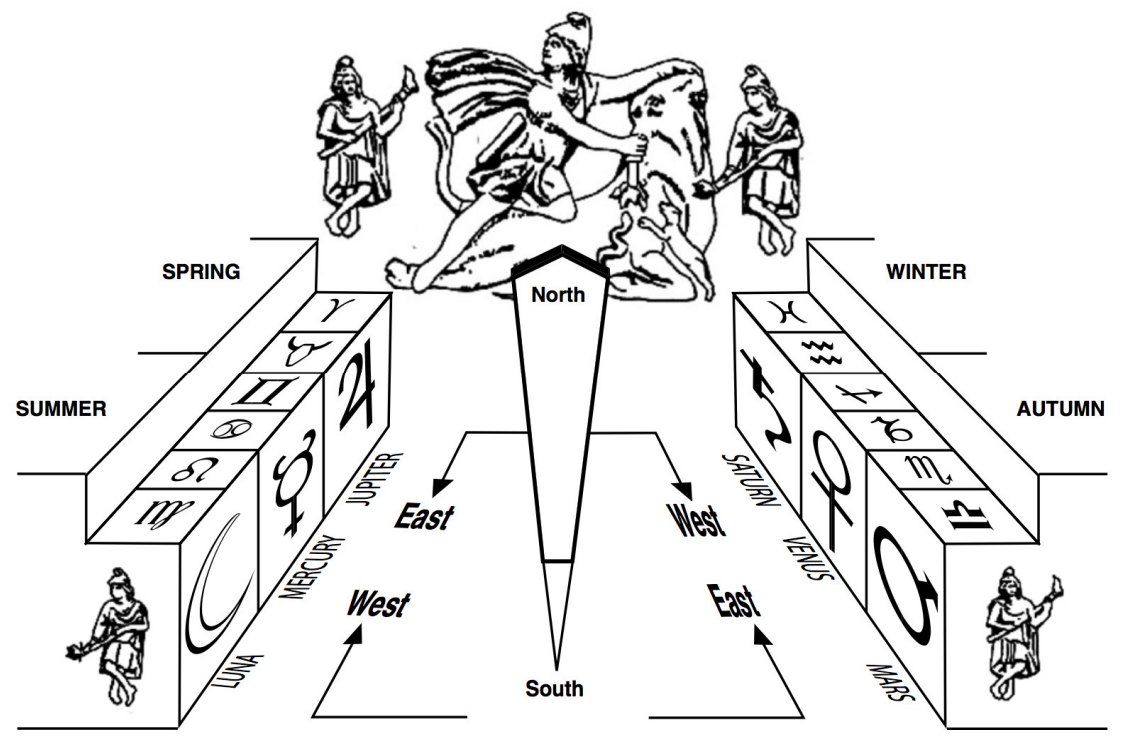

Fig. 3. The inner orientations i.e. sacred topography of the mithraeum by GORDON (n. 9) = BECK (n. 2) 104, fig. 3 (R. Gordon)

cult -niche

tauroctonous Sol Mithras

with equinoctial symbols

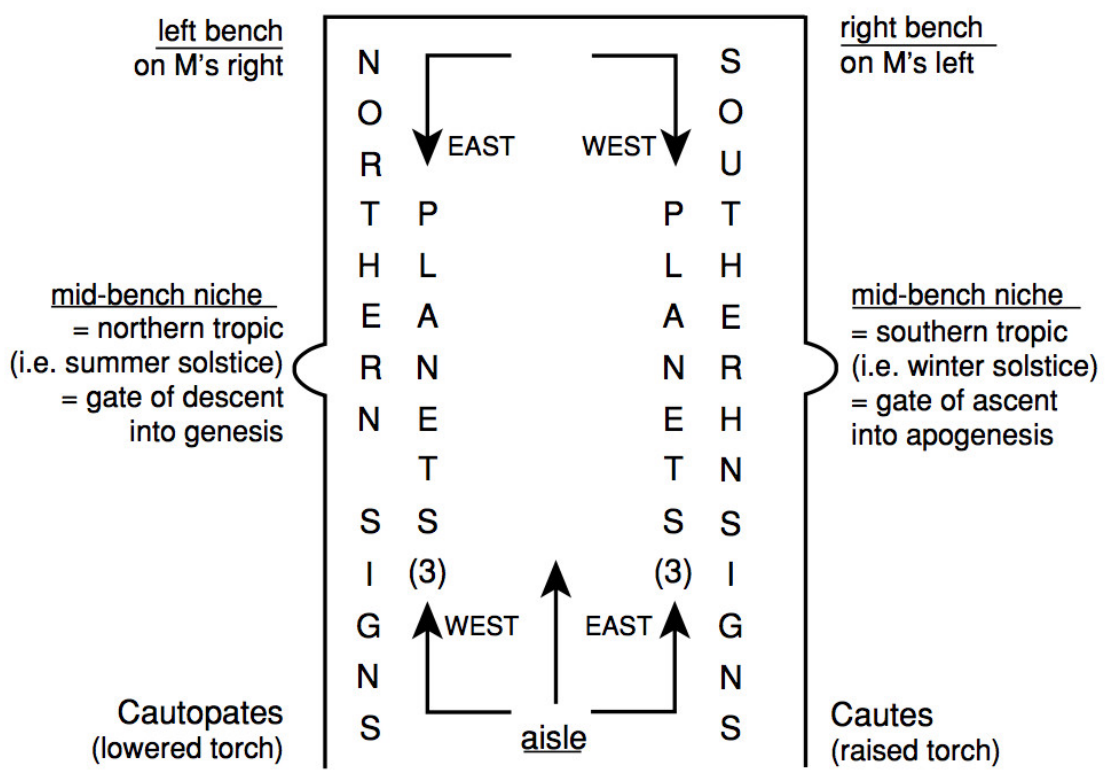

Fig. 4. The inner orientations i.e. sacred topography of the mithraeum by GORDON $1976=$ BECK (n. 2) 103, fig. 2 (R. Gordon) 


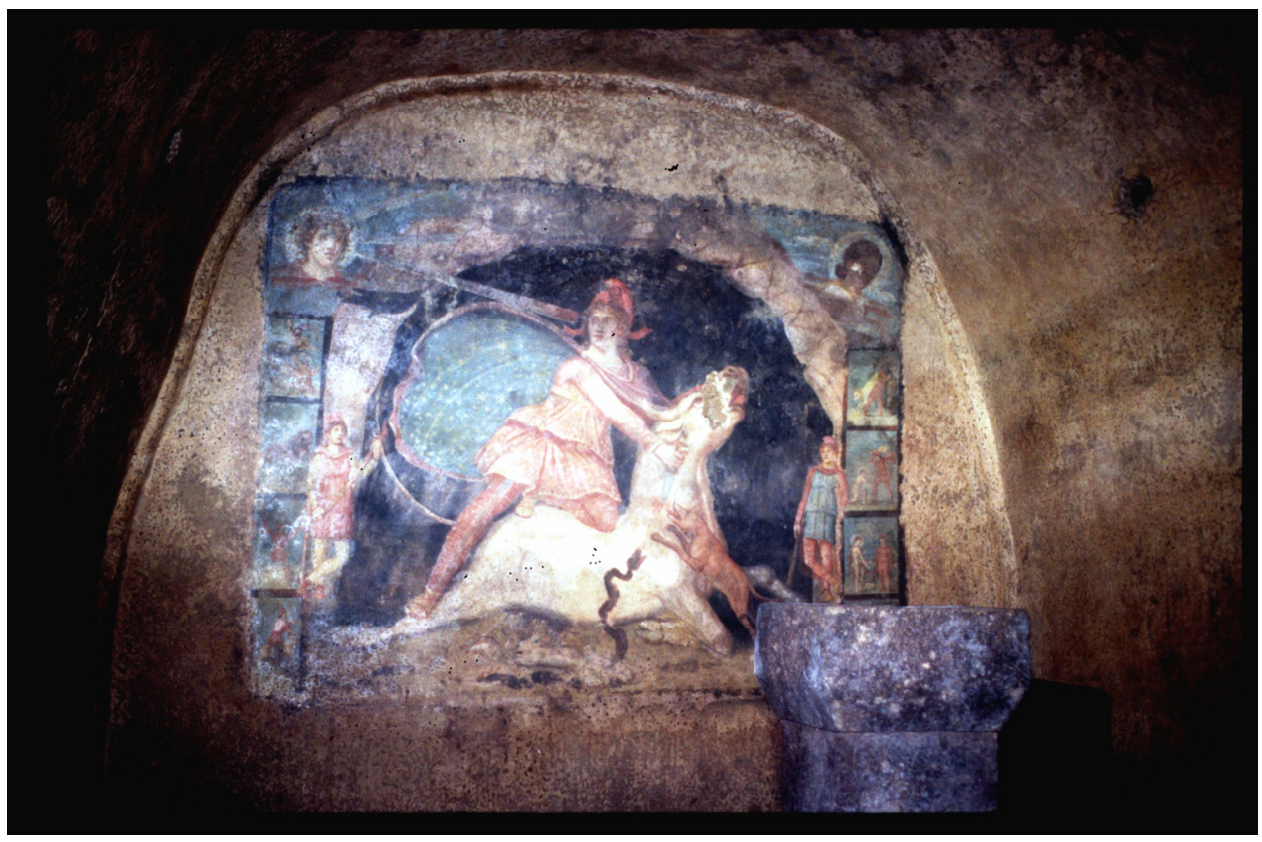

Fig. 5. The painted cult fresco of Marino Mithraeum (Italy) Photo by Z. Mazur (Nr. 63/1999)

The multidimensional aspects of the Mithraic "Cosmos" can be reconstructed through the identification of the cosmic directions depicted by symbols within the sanctuary. It is very important to note that the representation of the Cosmos in the sanctuary portrays only the visible, sensorial world. The Underworld, although it was an organic part of the Greek-Roman world view and religious thought (e.g. Hades, Orcus, etc.), was never explicit in literary, epigraphic, iconographic or archaeological sources in Mithraic contexts. ${ }^{11}$ Additionally, no Mithraic grave has been found, as well as there is no known Mithraic burial rite. It means that the burial in its physical form was not important for the initiates. During their life and after that, the initiates are placed in one of the spaces of the "Cosmos" represented by the sanctuary. This seems unquestionable after investigating the identified and known sources. If there is no Underworld, however, what was the primary purpose of coming to know the mysteries and taking part in a series of initiations?

\section{THE CULT IMAGE (SIMULACRUM)}

The main figures of the sculpted or painted cult image are constant, their place inside the scene is the same in the entire territory of the Roman Empire, between the 1st and

\footnotetext{
${ }^{11}$ Summarized by LÁSZLÓ-NAGY-SZABÓ (n. 1).
} 
4th centuries $\mathrm{AD}$. It means that in space and time they represented the same content all along (cf. figs $1-2,5)$.

The respective directions of the "Cosmos", represented by the interior of the sanctuary, are oriented adjusting to the inner system of navigation. Taking some of the aspects into consideration, we can even determine the theoretical direction of the two additional axes, which reach beyond the sanctuary, and locate the place of the cave i.e. the Cosmos or mithraeum, inside the Mithraic Universe. In addition to the sacred topography of the Cosmos, one can also detect a perpendicular structural rule, a next level system of inner orientation from the entrance to the ending wall, and beyond that - and perpendicular to it. The key to understand this inner rule is the painted or sculpted cult image, which stood regularly vis-à-vis to the entrance, on the opposite wall, or at the end of the cave. The outlines of the cave entrance represented on the cult image can be associated with the lateral walls and the ceiling of the sanctuary. Thus the cave on the cult image can be considered the 'continuation' of the sanctuary, as the other entrance in the cave. Its iconographic program summarized the basis and the essence of the content of the mysteries for the worshippers. ${ }^{12}$

There is only one direct literary account from the 4th century AD, focusing especially on the cult image: Saint Jerome reported that in Rome in 377, the praefectus Urbi searched for all the Mithraic cult images, in front of which they performed the initiations, and mutilated them to be useless. ${ }^{13}$

The cult image has the following representations, identified with some constellations, i.e. zodiac signs: ${ }^{14}$ the white bull (Taurus), Mithras, the young god holding a dagger in his right hand and the head of the bull in a scene of a sacrifice. His face turned backward or in front of the viewer, but never looking on the bull itself. On his cloak, numerous stars are represented (fig. 6). On both sides of him, two torchbearers, Cautes and Cautopates (Gemini). The one in the right usually holds up his torch, the left down. On his cloak sits a raven (Corvus). The tale of the bull ends in form of a spica (Virgo-Spica). At the bottom of the image, below the bull's belly a scorpion (Scorpius) hangs it's claws onto the animal's testicles. To the right, a heaving Snake (Hydra) is creeping along the whole length of the image. Its head is raised toward the wounded shoulder of the bull, from which blood flows. Toward the center of the

\footnotetext{
${ }^{12}$ Summarized by CAMpBell (n. 7) Cf. more Tóth (n. 6) 37-68.

${ }^{13}$ See Hieronymus, Epistula 107 (Ad Laetam) 2. 2: ... Et, ut omittam vetera, ne apud incredulos nimis fabulosa videantur ante paucos annos propinquus vester Graccus, nobilitatem patritiam nomine sonans, cum Praefecturam gereret Urbanam, nonne specum Mithrae, et omnia portentosa simulacra, quibus Corax, Nymphus, Miles, Leo, Perses, Helios, Dromo, Pater initiantur, subvertit, fregit, excussit:... Cf. more Prudentius, Contra Symmachum 1. 561-565.

${ }^{14}$ See InSLER, ST.: A New Interpretatin of the Bull-Slaying Motif. In DE BOER, M. B. - EDRIDGE, T. A. (éd.): Hommages à Maarten J. Vermaseren: recueil d'études offert par les auteurs de la série Études préliminaires aux religions orientales dans l'Empire romain à Maarten J. Vermaseren à l'occasion de son soixantième anniversaire le 7 avril 1978. Leiden 1978, 519-538; ULANSEY, D.: The Origins of the Mithraic Mysteries. Cosmology and Salvation in the Ancient World. New York 1990²; NoRTH, J. D.: Astronomical Symbolism in the Mithraic Religion. Centaurus 33 (1990) 115-148; SzABÓ, Á.: Das Verknüpfungselement der Sternbilder der Tauroktonosszene. Archaeologia Poetovionensis 3 (2001) 275-282.
} 


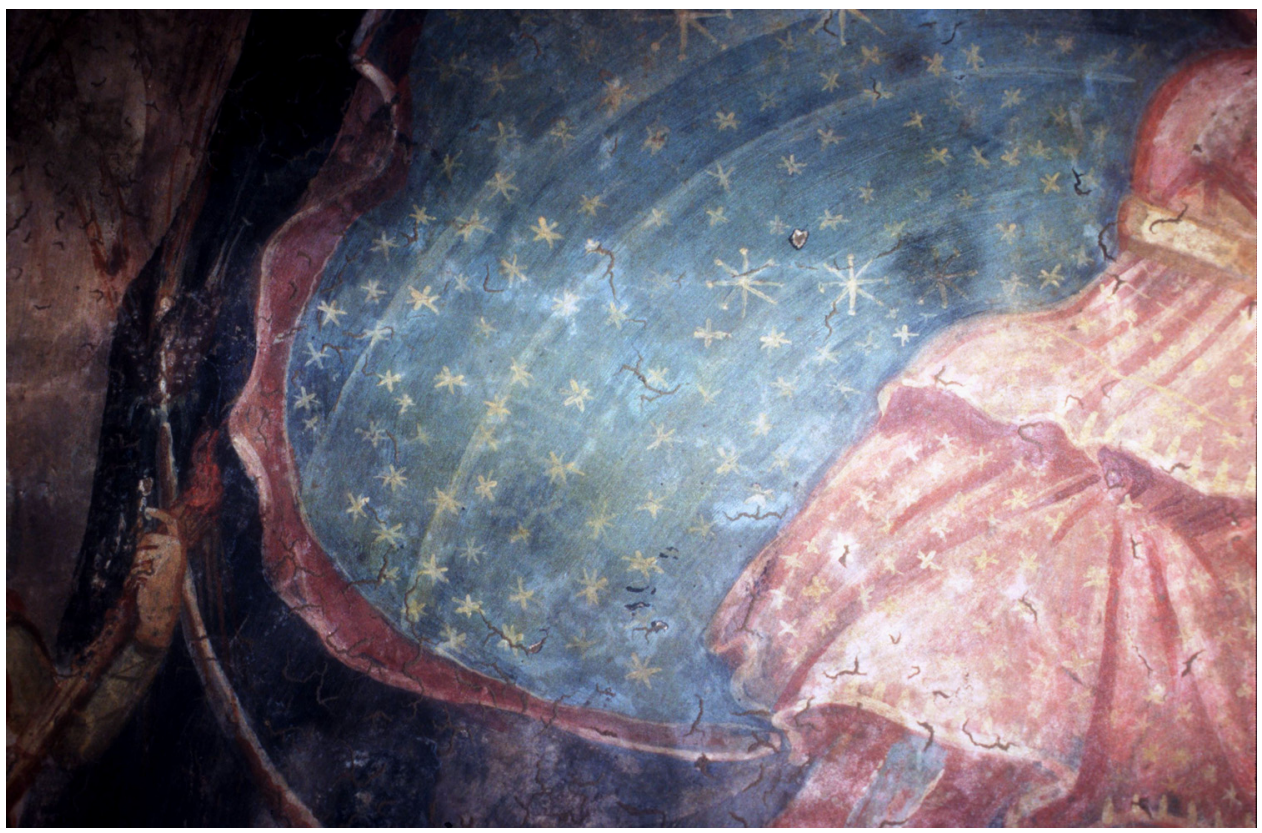

Fig. 6. Detail of the painted cult image from Marino Mithraeum (Italy). Photo by Z. Mazur (Nr. 73/1999)

snake's body, one can observe a lion (Leo) and a krater with two side handles (Crater). The line of accompanying figures is enclosed by a dog (Canis minor), which is depicted jumping to the right side of the bull's brisket. In addition to the previously recognized symbols, we may observe further celestial components. According to Porphyry, Mithras bears the dagger of the sign Aries, pertaining to Mars. The dagger is in the hand of Mithras. Thus, through this dagger the Aries constellation is also present on the cult relief. This idea is further elaborated by Porphyry: he claims that the celestial Mithras reclines against Taurus and Libra, both of them pertaining to Venus. The Libra is represented in an archaic tradition, by the scissors of the Scorpio. ${ }^{15}$ A depiction of the Milky Way is also apparent on the cult relief. ${ }^{16}$ I have considered heretofore that it was depicted by the wound of the bull gushing blood, though it is less likely. The blood of the bull relates better e.g. with the constellation of Eridanus, by way of its position and also its content bearing a mythological background. Equally, the Milky Way (Galaxias) could easily be identified - considering the depiction and placement - with the dense star depictions on the cloak of Mithras, currently preserved only on a handful of cult reliefs (see e.g. figs 5-6). ${ }^{17}$ The Milky Way is positioned to

${ }^{15}$ Cf. more BECK, R.: The Seat of Mithras at the Equinoxes: Porphyry De antro nympharum 24. Journal of Mithraic Studies 1 (1976) 95-98.

${ }^{16}$ See SZABÓ (n. 14) 275-282.

${ }^{17}$ Cf. EISLER, R.: Weltenmantel und Himmelszelt. München 1910. 
the north-south on the day of the Tauroctony in March, connecting the north and south celestial pole. Among the displayed constellations the period between the winter solstice and the spring equinox is absent.

The central scene and the accompanying figures are surrounded by the cave entrance walls in a semicircle. A rolled-up curtain was sometimes portrayed on the upper part of the vault, for example, see the already mentioned cult image of Marino (fig. 5), thus confirming that the event takes place at the entrance of the cave, in the area of the threshold. The background of the Tauroctony is usually painted dark, in order to suggest a sense of concealed gloominess. In the case of solid representations, the presentation of the main scene and its surroundings has quite a different set of possibilities. We have knowledge of large sculptures in rondo like the originally rendered statue of the Mithraeum of the Terme del Mitra (fig. 7), in Ostia, ${ }^{18}$ or the group of sculpture from the city of Rome, preserved in the British Museum. ${ }^{19}$ The latter can be accordingly evaluated, even if it lacks precise context, in contrast to the former, which - although found in situ, in its original position - its environment is rather bleak. The second one is probably from the Trajanic period. Its peculiar feature, besides that the head of Mithras was incorrectly restorated, is that it is one of the earliest known examples of its kind, known in the City of Rome and the entire Empire. All other similar examples have no precise finding place. They do not bear any information regarding the space arrangement of the sanctuary or the way they were displayed within. At the same time, the dark background depicted in the painted cult image suggests that behind the three dimensional Tauroctony scene darkness was also created. From the point of view of the topic discussed here, it is prominently important that the lengthwise of the Tauroctony sculpture, closed small angles with the lengthwise sidewalls of the mithraeum, namely the bull turns faceward to the entrance. The two dimensional cult images show the same movement, the attempt of the bull to enter into the cave. (fig. 8).

\section{THE ‘EXTERNAL’ ORIENTATION OF THE CULT IMAGE}

Over the entrance of the cave portrayed in the upper left corner of the cult image the rising Sun, and in the upper right corner the setting Moon appear together. The two continuous elements, constantly recurring celestial depictions on one hand indicate the cosmic context of the cavern and illustrated scenes, and on the other hand designate the compass points and orientation as well. On the right the Sun marks the East, on the left the Moon marks the West. The viewer accordingly views the cult relief from the 'North'. In addition, the main inner direction follow an 'North-South' axis, i.e. the mithraeum is oriented to 'South' from inside.

${ }^{18}$ Cf. BeCATti, G.: Scavi di Ostia. II: I Mitrei. Roma 1954, 29-38; CIMRM 229, 230.

${ }^{19}$ Cf. CIMRM 593 and 594 (CIL VI $\left.718=30818\right)$. 


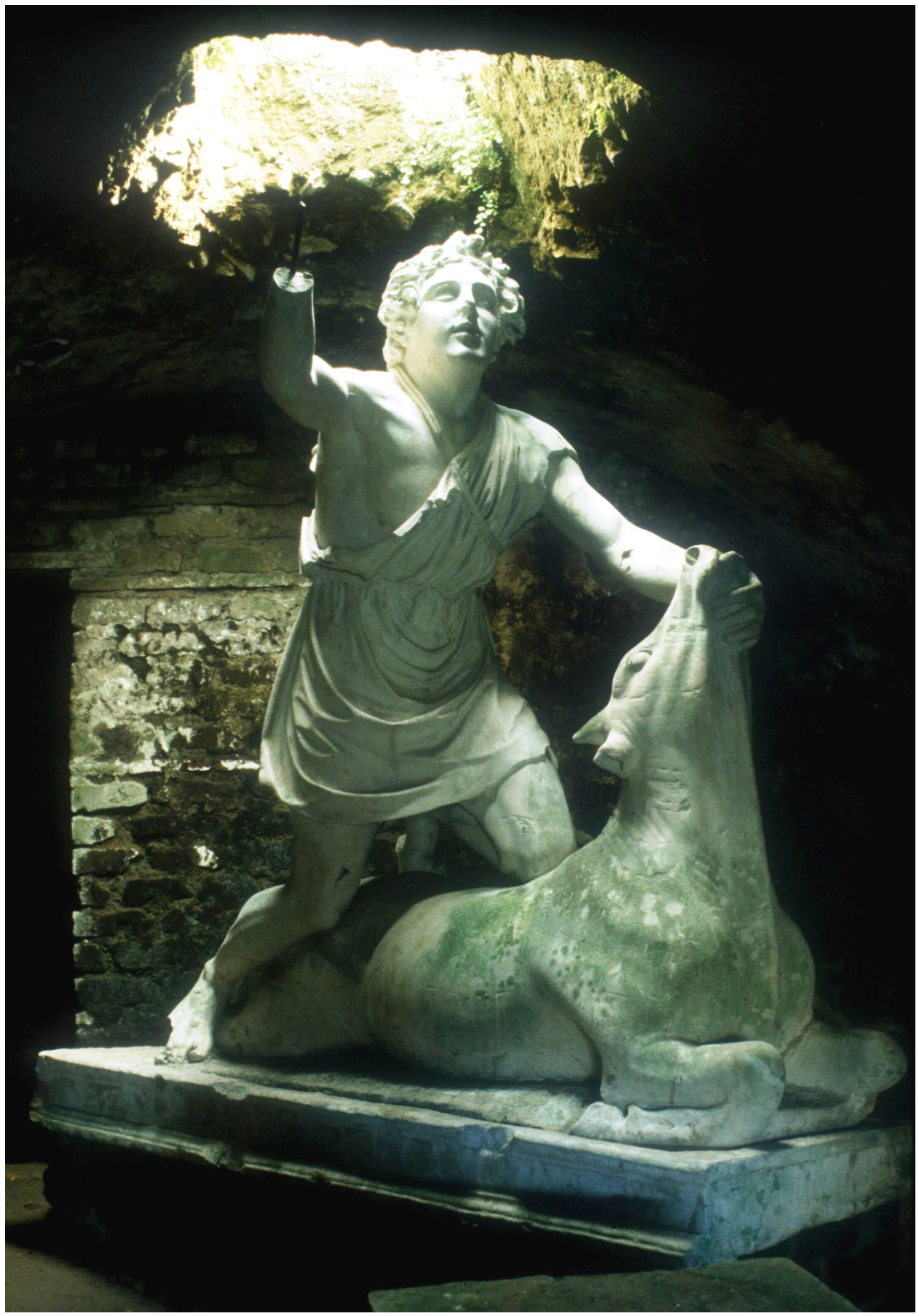

Fig. 7. Tauroctony sculpture, Terme del Mitra Mithraeum, Ostia (Italy). Photo by Z. Mazur (Nr. 57/1999) 


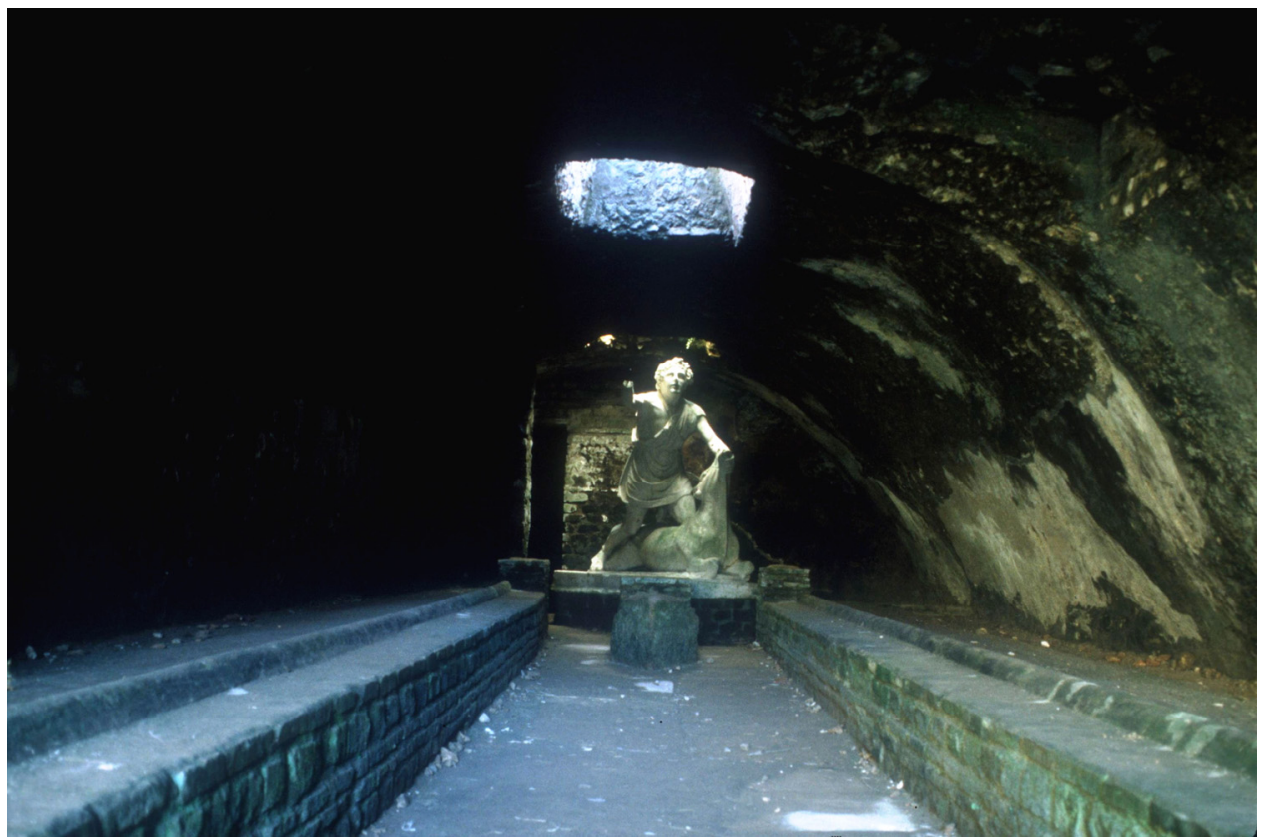

Fig. 8. The cave of the Terme del Mitra Mithraeum, Ostia (Italy). Photo by Z. Mazur (Nr. 67/1999)

\section{THE 'INTERNAL’ ORIENTATION OF THE CULT IMAGE}

The figures shown on the cult image are the representations of the constellations bearing the same name, in a given and transposed order. With them, the scene was organized both in time and space by the creator of the image in the 1st century AD. We see those constellations, which are surpassed by the Sun, under its apparent celestial path. The celestial area covered by the constellations, is complemented by the Milky Way. All together show the firmament in a period when all of the portrayed cosmic phenomena appear together in the sky. ${ }^{20}$ Mithras is the only one that is not clearly identifiable as a celestial sign, although its position is roughly equivalent to the Orion or Perseus constellation. ${ }^{21}$ The uncertainty of identification suggests that unlike the rest of the figures, he was only present in a given moment, on the occurence of the Tauroctony and represented himself in the scene.

Porphyry, who lived in the 3rd century, interpreted Book 13, lines 202-112 of Homer's Odyssey. ${ }^{22}$ In relation to the Nymph's cosmic cave, he discussed also some

${ }^{20}$ See SZABÓ (n. 14) 275-282.

${ }^{21}$ See SPeIDEL, M. P.: Mithras-Orion: Greek Hero and Roman Army God [EPRO 81]. Leiden 1980; UlANSEY (n. 14) 1990.

${ }^{22}$ Cf. Blomart, A.: Mithras and Porphyry: When Sculpture and Philosophy Meet. Revue de l'histoire des religions 210 (1993) 419-441. Cf. more TURCAN, R.: Mithras Platonicus. Recherches sur l'Hellénisation philosophique de Mithra [EPRO 47]. Leiden 1975. 
aspects on Mithras. According to him, Homer oriented the cave's entrances to the south and to the north, towards the southernmost and northernmost gates, that is, the poles of the sky. The cave is the shrine of souls, and the entrances are places of formation and passing. Mithras, the creator sits on the circle of the equinox, his place is defined by the two equinoxes. On his right side, we see the northern parts until the torch bearer, the cold Cautes; on his left side are the southern parts until the warm Cautes. ${ }^{23}$ The much-discussed description of Porphyry is essential to the understanding of the internal structure and the external arrangement within the Universe of the mithraeum, and the symbolism of the cult image. However, the cult image is also essential to the proper understanding and interpreting of Porphyry's text.

The cult image encloses the opposite side of the mithraeum entrance. The image forms a structural unity with the inner space of the sanctuary, which unity is depicted in two but should be understood in three dimensions. It does not act only as an architectural element or decorative item, but also in connection with the cave entrance depicted behind the cult image itself. For example, in the Mithraeum of Santa Maria Capua Vetere (Italy) the cult image covers the entire opposite wall (fig. 2), much alike a pictorial continuation of the sanctuary's inner space. ${ }^{24}$ The painted cult image of Marino (fig. 5), even though smaller in size, renders a realistic image of a cave entrance. ${ }^{25}$ Thus the cave entrance illustrated on the cult image, represents the south 'entrance' of the mithraeum interpreted by Porphyry as a cave. On the interior, at the edge of both sides we see Cautes on the left/right; and Cautopates on the right/left. Cautopates is holding a torch upward in his hand, which can be seen as a symbol of nascency, while Cautes is holding the torch downward, which in turn can be interpreted as a symbol of passing. Their position is either inside or outside the painted or sculpted cave entrance, that meant different viewing directions only. In the first case they can be interpreted together with the Tauroctony scene, in the second case with the sanctuary's interior. Their place is, by all means, on the sill. With these complex characteristics, they express several meanings at once. At the same time, they represent a south-west and a north-east region, i.e. directions too, which can be imagined only in space. All of this is illustrated and also confirmed e.g. by the in situ Tauroctony sculpture of the Terme del Mitra in Ostia. By way of their position, they also indicate that the bull charges from the southwest to the northeast, in the direction of the southernly 'entrance' facing the viewer, as if it were wanting to get into the mithraeum (fig. 7). This occurence is prevented by Mithras with his dagger.

The apparent celestial path of the Sun, i.e. the months from March till next March in their consecutive order, along Pisces-Aries-Taurus-...-..-SagittariusCapricorn-Pisces, the constellations of the relief, are located as follows: Aries (Mithras' dagger) to the right, with the Bull intersecting the path (Mithras center); a small part, one of the horns and the corresponding Pleiades are positioned to the right, Eridanus to the left. The Gemini are also intersected by the path right in the middle; the

${ }^{23}$ See Porphyrios, De antro Nympharum 24.

${ }^{24}$ Cf. CIMRM 181 and Vermaseren, M. J.: Mithriaca I: The Mithraeum at S. Maria Capua Vetere [EPRO 16]. Leiden 1971.

${ }^{25}$ Cf. Vermaseren, M. J.: Mithriaca III: The Mithraeum at Marino [EPRO 16] Leiden 1982. 
little Canis appears to the left; the Hydra to the left; the Lion is intersected by the path; we see the Crater to the left; the Raven to the right; the Libra is again intersected by the path; lastly we can see Scorpio placed on the left and the Snake on the right. What is located on the left of the celestial path of the Sun, is mostly positioned on the left side of the cult image, hence what is on the right, again is depicted on the right side of the relief. Those figures which have their counterpart constellation intersected by the celestial path of the Sun (the Celestial Equator, or Ecliptica) are also placed centerwise on the relief, some have their center point slightly shifted to either side. The Gemini is intersected exactly at midpoint, accordingly on the image they are arranged at the same distance from the center to the right and left. The Lion (Leo) is located under the belly of the Bull, being the constellation also intersected by the Sun's path, thus on the image we see the figure in the axis of the scene. The scissors of the Scorpio, namely (as explained above) the Libra are situated in the middle of the bull, but the Scorpio's body itself shifts more to the left. The Milky Way or Galaxias is also in the middle of the frame, captured in the moment of depiction along the north-south axis.

The representations of the cult image are arranged in correct order, perpendicular to the horizontal projection of the Celestial Equator. ${ }^{26}$ They are positioned in space between a Cautes and Cautopates forming a semi-circle along the north-south axis, arranged on both sides, or center in respect to their features attributed to the Underworld and the world of the living. The structure of the cult image complies with several other compositional aspects of philosophical origin, as well. ${ }^{27}$ In context of the sanctuary's interior space, the bottom segment of the image can be interpreted as the Celestial Equator proceeding through the Zodiac, as it has already been suggested. $^{28}$

On the cult images both the qualities of the Underworld and the world of the living were displayed, as illustrated by the Tauroctony scene. The Bull, an animal which symbolizes the image of a principal deity due to its color and sex, customarily served as a sacrifice to the celestial gods and the main god in the Greco-Roman world. In contrast, Mithras sacrifices the bull in an underworldly manner. His head is covered, he is not looking at the animal, and jabs the dagger in the neck artery, shedding his blood. ${ }^{29}$ Based on its complex symbolism, the event takes place on the border between the southern and northern parts of the Universe, in a well-defined point in time when the Milky Way is deviating towards the 'North-South' axis of the cave.

Altogether we can establish that the interior of a mithraeum is oriented along the 'North-South - East-West' frame of reference by the cult image, reinforcing these directions multiple times. At the same time, in this system the cult image divides the Mithraic universe up into northern and southern portions. The northern part of the Mithraic universe, as it is displayed, "the orderly world" or the "Cosmos" itself is

\footnotetext{
${ }^{26}$ Cf. BECK (n. 2) 32, fig. 1.

${ }^{27}$ TÓTH (n. 6) 37-68/97-134.

${ }^{28}$ Last time LÁSZLÓ-NAGY-SZABÓ (n. 1) I 245 with former literature.

${ }^{29}$ With many other aspects, cf. more TURCAN, R.: Le sacrifice mithriaque: innovations de sens et de modalités. Entretiens sur l'antiquité classique 27 (1981) 341-380.
} 
represented by the shrine. Its opposite, the southern part, "disorderly world" or "AntiCosmos' is absent on the cult image. At most, it appears on painted variations of the scene, in the form of a dark-toned background. Investigating according to the contemporary view non-related to Mithraism, the combined structural symbolism of the cult image and the sanctuary, and the displayed and evoked content, we can determine that the equivalent of the world of the living or the "Cosmos" is the "North" whilst the Underworld or the 'Anti-Cosmos' is analogous to the 'South'. The Tauroctony prevents the specifically represented Underworld and its principles to manifest (cf. fig. 9).

\section{CONCLUSION}

The most important achievement of the Mithras mysteries, its cult and its main appeal in the era was its philosophy that the soul, the component of every human that is independent from the body, can stay in the perceptible, earthly world after the death of the person. In other words, the soul can avoid the Underworld, the place that, according to earlier tradition, is inevitable. Contrarily, the person can be part of the world of gods and heroes represented in forms of the planets and constellations, and in the meantime can also remain within the world of the living, where earthly life takes place. This world was the multiple-sphered "Cosmos", represented in miniature by each sanctuary. This world, however, was available only to those who passed initiations. To obtain the knowledge that prepared them for the afterlife, they needed to learn the Mithraic narratives and doctrines well.

By contrasting the lived "Cosmos" with the world of death, or the "Anti-Cosmos', and the perspective of a possible earthly alternative in avoinding the latter, was the greatest discovery of the founder of the mysteries. Excluding the Underworld from the possible spheres of life-cycle was not an option before. For the people in the Greco-Roman world, passing to the Underworld represented a very real and sorrowful reality, even though they mostly came across scarce information from mythological depictions. Nobody could share their real-life experience of it. The average person descended into the Underworld after their life ended, to be reduced to the exact opposite of their earthly existence. This descension implied not only the death of the body, but also the decease of the soul. The Underworld did not allow for any continuation of earthly life, it meant total and memory-free passing. All forms of life remained within the borders of the perceptible "Cosmos". Thus the Underworld was the opposite of the organized "Cosmos", a certain type of 'Anti-Cosmos'. To be liberated from the possibility of total death was the main aim of the mystery religions. In the Roman period, numerous similar religions offered their systems and within them, different kinds of possibilities, or at least hopes of avoiding death, ranging from rebirth to resurrection.

To its initiates, the mysteries of Mithras offered the possibility to stay in the living "Cosmos", instead of passing to the Underworld after their life on Earth had terminated. Therefore, for the mystes of the mysteries, the Underworld ceased to exist completely. 


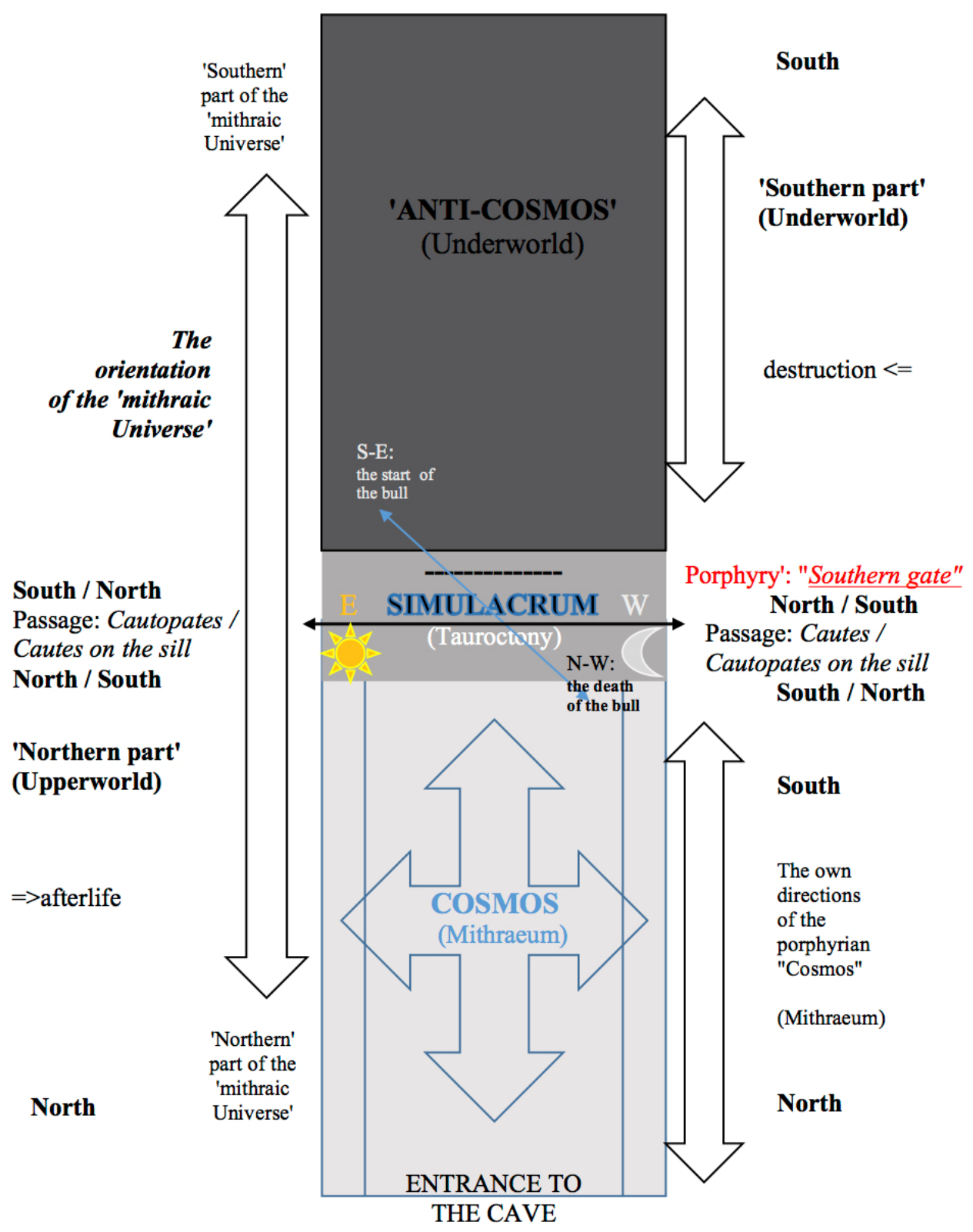

\section{Porphyry': "Northern gate"}

Fig. 9. The parts of the Mithraic "Universe". A sketch by Á. Szabó 
The act which separated the Underworld from the "Cosmos" was certainly the Tauroctony represented on the cult images. ${ }^{30}$ The event could have been explained in detail by the sacral story, a myth of Mithras. ${ }^{31}$ The following movement, after the Tauroctony is illustrated by the Transitus scene, as Mithras carried the killed bull ('Mithras taurophorus') inside in the 'Northern part'. The occurence has been well illustrated by the top right side-scene of the cult fresco from Marino: Mithras carried the corpse, standing before the south entrance of the shrine (i.e. the mithraeum), and asked for intromission (see fig. 10 and cf. fig. 11).

The 'Northern part' (i.e. the "Cosmos") is also the place of the birth of souls according to Porphyry. The birth in this case represents the rebirth through initiation. After the event of the Tauroctony, the initiated mortals had the possibility to remain in the known "Cosmos", even if only in a mutated form; that is to say, live on as souls in one of the celestial spheres. These Mithraic spheres are represented in a specific way e.g. in the sanctuaries of Sette Sfere and Sette Porte in Ostia. ${ }^{32}$

Confronting the cave-image of Porphyry with the specificities of the ground plan of the sanctuaries and the iconography of the cult images gave the possiblity for a new coordinate-system. The alineation of the new coordinates are perpendicular to the previously discovered orientations. Along these lines, the 'Mithraic Universe' can be imagined, and should be interpreted in three dimensions. In this system, the sanctuary is interpreted as 'up', while the background of the relief as 'down'. This dimension is relevant only in earthly circumstances, since in the Universe there is no up or down, or left and right. The two coordinate systems are perpendicular to, and integrated with each other, detailing the parts of the Mithraic "Cosmos" in the inner space of the sanctuary, and placing the Mithraic "Cosmos" in the "Mithraic Universe'.

The known and organised porphyrian "Cosmos", the northern part of the "Mithraic Universe', is the sanctuary itself, with its own inner coordinates. The rituals are performed here, from the evocation of the initiation ("descending"), the initiation itself ("rebirth") and leaving as initiated ("ascending"). In the sacred topography of this "northern" part of the 'Mithraic Universe' (i.e. the "Cosmos"), another, vertical and horizontal North-South and East-West doctrinal coordinate-system predominate (cf. figs 3-4) the cult-ceremonials. ${ }^{33}$

In short, it is statable that behind the cult relief lies the 'southern', the unorganized part of the 'Universe', the 'Anti-Cosmos' or the Underworld, that had been abol-

${ }^{30}$ Cf. more BIANCHI, U.: The Religio-Historical Question of the Mysteries of Mithra. In BIANCHI, U. (ed.): Mysteria Mithrae. Proceedings of the International Seminar on the "Religio-Historical Character of Roman Mithraism, with Particular Reference to Roman and Ostian Sources", Rome and Ostia, 28-31. March 1978 [EPRO 80]. Leiden 1979, 3-60, here 25 and SFAMENI GASPARRO, G.: Il mitraismo nell'ambito della fenomenologia misterica. In Mysteria Mithrae 299-348, here 327. $218-257$.

${ }^{31}$ Cf. Merkelbach, R.: Die Kosmogonie der Mithrasmysterien. Eranos Jahrbuch 34 (1965)

${ }^{32}$ See CIMRM 239 and 287. Cf. more BECATtI (n. 18); BECK, R.: Sette Sfere, Sette Porte, and the Spring Equinoxes of A.D. 172 and 173. In Mysteria Mithrae (n. 30) 515-530.

${ }^{33}$ See GORDON (n. 9) 119-165; LÁsZló-NAGY-SZABÓ (n. 1) 238-252; BeCK (n. 2) 102-120. 


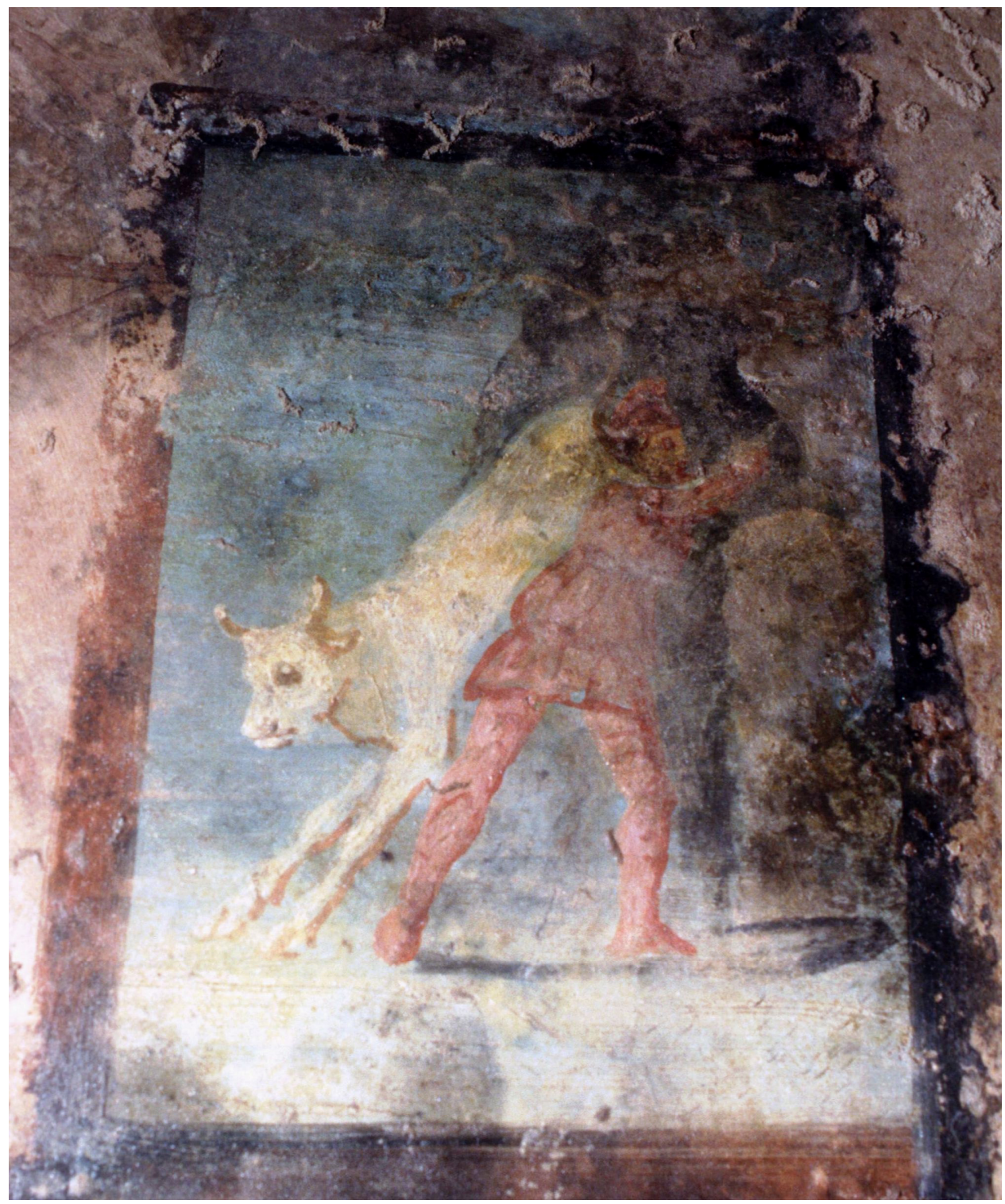

Fig. 10. Mithras carried the killed bull, on the right side of the entrance from "South" of the cave; Marino Mithraeum (Italy) cult image, detail. Photo by Z. Mazur (Nr. 69/1999)

ished from the Mithraic world, completely unmentioned by literary sources, which reperesented the opposition to the organized part of the 'Universe', the "Cosmos" or the world of the living. The cult image, also as a partition, divides the two parts of the 'Mithraic Universe', beside being a passage as well. 


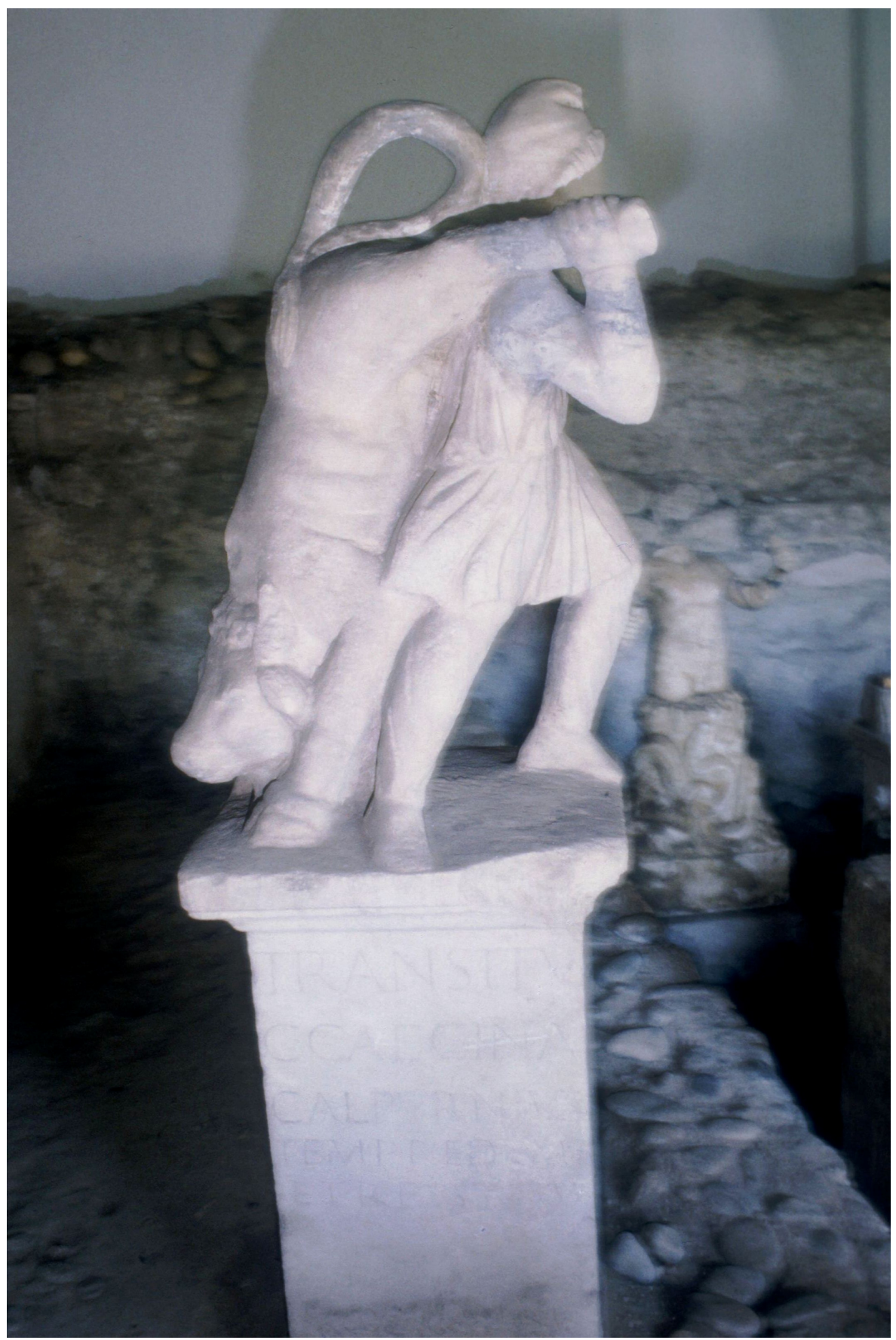

Fig. 11. Mithras carried the killed bull, Mithraeum I. Poetovio (Ptuj, Slovenia; cf. CIMRM Nr. 1494-1495). Photo by Z. Mazur (Nr. 96/1999) 


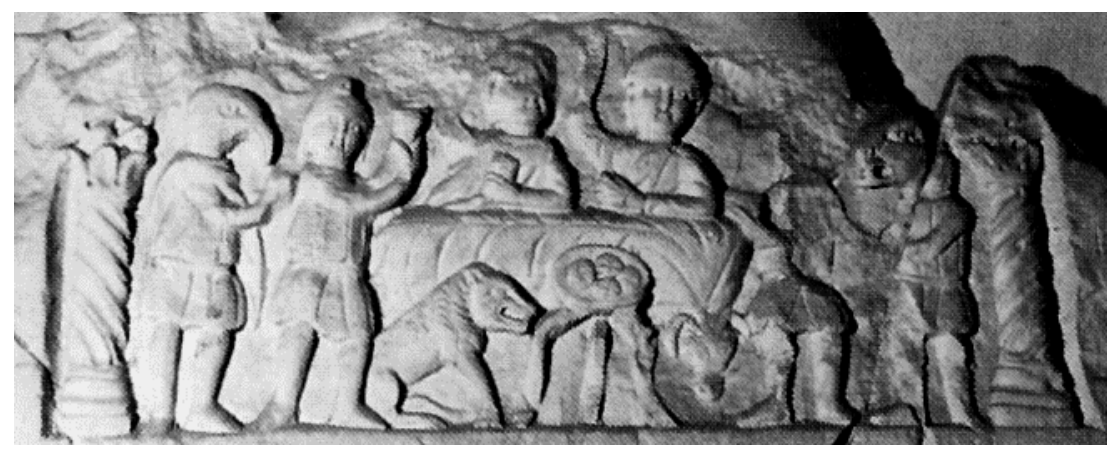

Fig. 12. Backside of the relief from Konjic (Bosnia-Hercegovina). Photo by Z. Mazur (Nr. 114/1999)

\section{THE HIDING OF THE SIMULACRUM}

In connection with the interpretation described above, an important detail is represented by the rolled up courtain, appearing mostly on painted cult images (e.g. Marino, Santa Maria Capua Vetere, see figs 2 and 5) or sometimes on carved reliefs (e.g. Dura Europos ${ }^{34}$ ). It is possible, that a real curtain was mounted above the statue representations of the Tauroctony, which was possibly let down and pulled up in front of the Tauroctony during certain rituals, for fixed amounts of time.

Veiling and unveiling the central relief could be related to the day of the Tauroctony in March, and the picture of the Underworld at the southern entrance of the cave. Throughout the major part of the year, the cult relief was probably veiled by the curtain, representing phyisically the closed state of the entrance of the Underworld. Lifting the courtain up was reasonable and safe only on the feast-day of the Tauroctony through adequate rituals.

The two side images represented a specific and very rarely used alternative for the curtains, attested in cult images for example in Konjic (Bosnia) ${ }^{35}$ (fig. 12), Fiano Romano (Italy) ${ }^{36}$ and Dieburg (Germany). ${ }^{37}$ All of them could be inverted and placed back into their frames, thus throughout the year the Tauroctony image was hidden. The backgrounds depict feast and banquet scenes, providing a proper setting for the regular assemblies of the worshippers. Other rituals and activities of the mysteries

\footnotetext{
${ }^{34}$ Cf. Rostovtzeff, M.: Das Mithraeum von Dura. Mitteilungen des deutschen archäologischen Instituts 49 (1934) 180-207; CIMRM 34.

${ }^{35}$ Cf. PATSCH, K.: Mithraeum u Konjicu [Glasnik zemalisk. Muzeja u Bosni i Hercegovini]. Sarajevo 1897; CIMRM 1896.

${ }^{36}$ Cf. CUMONT, F.: Un basrelief mithriaque du Louvre. Revue Archéologique 6 (1946) 183-195; CIMRM 641.

${ }^{37}$ Cf. Clemen, C.: Mithras-Mysterien und Germanische Religion. Archiv für Religionswissenschaft 34 (1937) 217-226; CIMRM 1946.
} 
were probably carried out in cyclic order, based on a sacred calendar, aligned to the current personification of the sanctuary. ${ }^{38}$

The interpretation outlined above presents a newly discovered detail, shedding light on one of the foundations in the appeal of the mysteries: that Mithras closed the way to total destruction, thus securing an afterlife after earthly death for his initiated worshippers.

The belief system of the Mithraic mysteries fits perfectly into the other, more or less known religious currents of that era. Not only with its main aim, but by using articulate symbols and ritual techniques in the confines of its own interpretation, symbols and rituals well known in that period and easily recognizable among the religious practice of other contemporary religions and cults as well. ${ }^{39}$

\author{
Ádám Szabó \\ Hungarian National Museum \\ Budapest \\ szabo.adam@hnm.hu
}

${ }^{38}$ Cf. e.g. Тóth (n. 6).

${ }^{39}$ Cf. e.g. Johnston, S. I.: Rider in the Sky. Cavalier Gods and Theurgic Salvation in the Second Century A.D. Classical Philology 87 (1992) 303-321; BEMMER, J. N.: Initiation into the Mysteries of the Ancient World [Münchner Vorlesungen zu Antiken Welten]. Berlin-Boston 2014, 110-141. 